\title{
Effect of Dietary Supplementation of Probiotics (Addon Poultry Max) on Biochemical and Immune Parameters in Commercial Broiler Chicken
}

\author{
M. Vijay Kumar ${ }^{1 *}$, Vivek M. Patil ${ }^{2}$, M. Kiran ${ }^{3}$ and S.M. Tendulkar ${ }^{4}$ \\ ${ }^{1}$ Department of Veterinary Pharmacology \& Toxicology, Veterinary College, KVAFSU, Bidar \\ (KS)-585401, India \\ ${ }^{2}$ LRIC (Deoni), KVAFSU, Bidar (KS)-585401, India \\ ${ }^{3}$ Department of Veterinary Livestock Products Technology, Veterinary College, KVAFSU, \\ Bidar (KS)-585401, India \\ ${ }^{4}(R \& D)$, Virbac India Pvt. Ltd., India \\ *Corresponding author
}

\section{A B S T R A C T}

Two hundred and forty, day old chicks were distributed randomly into four treatments with three replicates in each treatment ( 20 birds in each replicate) and were fed standard feed. The trial was studied for 42 days which comprised of four dietary treatments wherein T1

\section{Keywords}

Probiotics (Addon

Poultry Max),

Biochemical, Immune, Broilers

Article Info

Accepted:

12 September 2018

Available Online:

10 October 2018 served as basal diet. Basal diet+ 250g/ton (AGP), basal diet + Addon Poultry Max $(250 \mathrm{~g} / \mathrm{ton})$ and basal diet + Probiotics (Addon Poultry Max) (250g/ton) and Enrofloxacin $(10 \mathrm{ml} / 100 \mathrm{~kg} \mathrm{BW})$ levels were designated as T2, T3 and T4 respectively. Effects of different treatment groups on serum biochemical (total protein, cholesterol) parameters and immune response (CMI to PHA-P, HI to ND vaccine) were evaluated. The humoral immune response to $\mathrm{SRBC}$ indicated insignificant $(\mathrm{P}>0.05)$ influence, while CMI response with P-HAP was significantly $(\mathrm{P}<0.05)$ higher in broilers raised on Probiotics (Addon Poultry Max) supplemented groups compared to the control group. Concentration of serum cholesterol was not affected due to treatments. However, numerically lower total serum cholesterol values were observed in Probiotics (Addon Poultry Max) supplemented when compared to control group. The highest serum total protein value was observed with Probiotic (Addon Poultry Max) $(5.49 \mathrm{~g} / 100 \mathrm{ml})$ followed by T4 group (4.95 g/100ml) during sixth week. Hence, it can be concluded that, supplementation of Probiotic (Addon Poultry Max) as alternative to antibiotic can be used for improving performance of broiler chicken.

\section{Introduction}

Broiler production has become an important economic activity all over the world in the last few decades. India, large with an annual production (BAHS, 2015) of around 73.21 billion eggs and 3.725 million metric tons of poultry meat, ranks $3^{\text {rd }}$ in egg production and $7^{\text {th }}$ in broiler meat production, respectively, in the world. Antibiotics have been used as growth promoters for more than 5 decades in the feed industry to get advantage of increasing protection against some diseases, toxins, increasing nutrients absorption in 
intestine. However, because of the possible development of resistance by pathogenic bacteria against antibiotics, their efficacy was reduced besides public health impact due to their residues in eggs and meat. The Probiotics are reported to regulate gut integrity, enhance useful microbial environment, reduce digestive disorders, improve nutrient absorption and utilization, increases production and check the mortality. The Probiotics may provide an alternative to the administration of sub therapeutic levels of antibiotics in preventing the colonization of the gastro intestinal tract by unfavorable microorganisms. Probitoics act in tandem with adhesion receptors on the gut epithelium, with nutrients, produce antibacterial substances, stimulate immunity and reduce mortality. The supplementation of Probiotics to the diet significantly improved the live weight and feed conversion ratio of the chicken (Roozbeh et al., 2012).

Antibiotics and Probiotics are used separately as feed additives in poultry rations for the positive growth response but the information on combined feeding of those feed additives is limited further more information is available on alternative feeding of antibiotic and Probiotics and viceversa. Similarly more information is also available on the immune modulating effect on Probiotics.

Hence, the present study was designed to explore the influence of antibiotic \& Probitoics (Addon Poultry Max) and their combination feeding on broiler immune performance and biochemical parameters of blood.

\section{Materials and Methods}

Two Hundred and Forty birds were housed in each deep litter with an average floor space of 82 square inches or 205 sq. cm per bird. Feed and water were offered $a d l i b$. and the birds were raised under identical management conditions. The routine vaccination schedule was followed. A growth rial was conducted in randomized block design, comprising of four dietary treatments, where in first treatment (T1) served as basal diet. Basal diet + $250 \mathrm{~g} /$ ton (AGP), basal diet +250g/ton Probiotic (Addon Poultry Max), (basal diet + 250g/ton of Probiotic (Addon Poultry Max) and Enrofloxacin 1oml/100kg BW) levels were designated as $\mathrm{T} 1, \mathrm{~T} 2, \mathrm{~T} 3$, and $\mathrm{T} 4$, respectively. Three replicates were allocated to each of the treatments, employing twenty birds/replicate. Probiotic is proprietary commercial Add on Poultry Max product, prepared by Virbac Indian Private limited company, Mumbai. It is a mixture of Bacillus coagulans $1.5 \times 10^{9} \quad$ Bacillus licheniformis $0.8 \times 10^{9}, \quad$ Bacillus subtilis $1.5 \times 10^{9}$ Lactobacillus acidophilus $0.2 \mathrm{X} 10$.

\section{Immuneparameters}

The effect of feeding of Addon Poultry Max on immune response of broilers was studied by measuring the following parameters.

\section{Humoral immune response to NDV}

Blood samples were collected from eight birds individually from each dietary group at $42^{\text {nd }}$ day of age and antibodies specific for Newcastle disease Vaccine were measured in serum of chicks by haemagglutination inhibition (HI) test and were expressed as SRBC titers $\log 2$ (Allan et al.,1978).

\section{Evaluation of cell mediated immuneresponse}

Cell mediated immune (CMI) response was evaluated by cutaneous basophilic hypersensitivity $(\mathrm{CBH})$ test by injecting $100 \mu \mathrm{g}$ phytohaemagglutin - P (PHA-P) in $0.1 \mathrm{ml}$ of NSS into toe web of eight birds from each dietary group. Thickness was measured 
at 24 hours after injection and $\mathrm{CBH}$ was calculated using the formula (Edelman et al., 1986).

\section{Serum parameters}

On day $21^{\text {st }}$ and $42^{\text {nd }}$, blood from one representative bird from each replicate was collected in a clean sterile glass tube and kept in a slanted position at room temperature to facilitate the separation of serum for estimation of cholesterol and Total protein by using spectrophotometer with commercially available kits (Arkray Health care private Limited).

\section{Serum analysis}

$2 \mathrm{ml}$ of blood was collected from the wing vein using 2-3 $\mathrm{ml}$ syringe into an eppondrof tube. Then the blood was incubated from 2-3 hrs at $37^{\circ} \mathrm{C}$ and then centrifuged at 10,000 rpm for 6 minutes. Then the serum was separated and collected into another eppendrof tube and stored at $-20^{\circ} \mathrm{C}$ for serum analysis.

\section{Cholesterol}

Cholesterol was estimated in serum using kit number- 83LS100-40 (Arkray Healthcare private Limited). The reagent of $1000 \mu \mathrm{l}$ was taken in a cuvette, to it, $10 \mu \mathrm{l}$ of sample was added. This was incubated for 10 minutes and read at $505 \mathrm{~nm}$ (409-510nm). Then the optical density values were noted down and calculated.

\section{Total protein}

Total protein was estimated in serum using kit number- 71LS200-40 (Arkray Healthcare private Limited). The reagent of $1000 \mu 1$ was taken in a clean cuvette (by rising with distilled water), and $10 \mu 1$ of serum sample was added and mixed well and incubated at 20$26^{\circ} \mathrm{C}$ for 30 minutes and then read at $578 \mathrm{~nm}$
$(550-580 \mathrm{~nm})$. Then the optical density values were noted down and calculated.

\section{Results and Discussion}

\section{Immune organs}

The present experiment revealed that the data on immune competence in broiler chicken was influenced by different dietary treatments with Probiotic (Addon Poultry Max) fed diets are presented in Table 1. The study revealed no significant difference in the relative weights of spleen and thymus at $42^{\text {nd }}$ day of age. The relative spleen weight was higher in control $(0.133 \mathrm{~g})$, then followed by Probiotc (Addon Poultry Max @ 250g/ton (0.1145). The relative thymus weight was higher in Probiotc (Addon Poultry Max) (0.347g) and least in control group. However, the supplementation of Probiotc (Addon Poultry Max s significantly) $(\mathrm{P}<0.05)$ improve the relative weight of bursa at 42 dosage. The higher bursa weight was observed with Probiotc (Addon Poultry Max) (250g/ton) when compared to all other group.

Immune organs of broilers were not significantly influenced by all the dietary supplementations of Probiotc (Addon Poultry Max) and their combination with antibiotic. But bursa was highest in Probiotc (Addon Poultry Max) supplemented group. These findings are in agreement with the results of Rama Rao et al., (2004) who observed higher lymphoid organ (bursa, spleen) weights in broilers fed Probiotics diet. Contrary to these findings, Panda et al., (1999) observed lack of difference in the live weight of spleen and bursa in Probiotics supplemented groups.

\section{Humoral immune response}

The data on humoral immunity was evaluated in terms of antibody response to Sheep Red Blood Cell at $42^{\text {nd }}$ of age in broiler chicken as 
influenced by different dietary treatments with Probiotics (Addon Poultry Max) fed diets are presented in Table 2. The mean, $\log 2$ antibody response to SRBC were not significant at $42^{\text {nd }}$ day of age and mean $\log 2$ titer value was higher in Probiotic (Addon Poultry Max @ $250 \mathrm{~g} / \mathrm{ton}(9.75)$ and low in antibiotic @ $250 \mathrm{~g} /$ ton $(9.25)$ group.

The humoral immunity was evaluated in terms of antibody response to SRBC at $42^{\text {nd }}$ day of age using HA assay. The mean $\log 2$ titer values were higher in all test diets compared to control. Similar findings were also observed by Panda et al., (1999) who reported that supplementation of Probiotics did not have any significant effect on antibody production against SRBC.
In contrary to this Kabir et al., (2004); Khaksefidi and Ghoorchi (2006); Nayebpor et al., (2007) observed that significantly $(\mathrm{P}<0.01)$ higher antibody production in experimental birds as compared to control group.

Increased titer values against SRBC might be due to the effect of Probiotics (Addon Poultry Max), on immune system or improved intestinal absorption of some nutrients such as $\mathrm{Zn}, \mathrm{Cu}$ and $\mathrm{Se}$. The higher lymphoid organ weight (bursa and spleen) also supports the increased immune response in test groups. The reduced gut $\mathrm{pH}$ and pathogenic bacteria in intestine, increased weight of lymphoid organs which might have acted indirectly to enhance the immune competence in broilers.

Table.1 Effect of Probiotic (Addon Poultry Max) on relative immune organ weights of broiler chicken at 42 days of age $(\mathrm{N}=6)$

\begin{tabular}{|l|l|l|l|}
\hline Diets & \multicolumn{3}{|c|}{ Relative weights } \\
\hline T1 & Spleen & Thymus & Bursa \\
\hline T2 & 0.0919 & 0.322 & $\mathbf{0 . 0 7 4 ^ { b }}$ \\
\hline T3 & 0.1101 & 0.323 & $0.084^{\mathbf{b}}$ \\
\hline T4 & 0.1330 & 0.347 & $0.100^{\mathbf{b}}$ \\
\hline P Value & 0.1145 & 0.334 & $0.098^{b}$ \\
\hline SEM & 0.345 & 0.984 & $\mathbf{0 . 0 0 1}$ \\
\hline
\end{tabular}

Table.2 Effect of dietary inclusion of Addon Poultry Max on Immune Response in broiler chicken at $42^{\text {nd }}$ day of age $(\mathrm{N}=8)$

\begin{tabular}{|l|c|c|}
\hline Diets & *PHA-P response (thickness index) & SRBC titers $(\log 2)$ \\
\hline & $6^{\text {th }}$ week & $6^{\text {th }}$ week \\
\hline T1 & $109.0^{\mathrm{b}}$ & 9.5 \\
\hline T2 & $154.0^{\mathrm{b}}$ & 9.25 \\
\hline T3 & $113.9^{\mathrm{b}}$ & 9.75 \\
\hline T4 & $126.3^{\mathrm{b}}$ & 9.75 \\
\hline P Value & 0.001 & $\mathbf{0 . 6 4}$ \\
\hline SEM & 28.64 & $\mathbf{1 . 1 2 9}$ \\
\hline
\end{tabular}

*PHA-P: Phytohaemaglutinin-phosphate Show level of significance @ P>0.01 
Table.3 Effect of dietary inclusion of Addon Poultry Max on Serum biochemical profile in broiler chicken at $21^{\text {st }}$ and $42^{\text {nd }}$ day of age $(\mathrm{N}=8)$

\begin{tabular}{|l|c|c|c|c|}
\hline Diets & \multicolumn{2}{|c|}{ Cholesterol $(\mathbf{m g} / \mathbf{1 0 0} \mathbf{m l})$} & \multicolumn{2}{|c|}{ Total Protein $(\mathbf{g} / \mathbf{1 0 0} \mathbf{m l})$} \\
\hline & $\mathbf{3}^{\text {rd }}$ week & $\mathbf{6}^{\text {th }}$ week & $\mathbf{3}^{\text {rd }}$ week & $\mathbf{6}^{\text {th }}$ week \\
\hline T1 & 199.1 & 184.0 & 3.53 & 4.66 \\
\hline T2 & 192.9 & 182.3 & 3.55 & 4.71 \\
\hline T3 & 178.5 & 180.3 & 3.79 & 5.49 \\
\hline T4 & 187.5 & 182.0 & 3.70 & 4.95 \\
\hline
\end{tabular}

Mean bearing at least one common superscript in a column do not differ significantly $(\mathrm{P}>0.05)$

\section{Cell Mediated Immunity}

The present experiment revealed that the data in Table 2. There is no significant difference was observed in PHA-P (thickness index) response among all dietary treatments but numerically higher PHA-P (thickness index) response was noticed in all test diets compared to control group at the age of $42^{\text {nd }}$ day.

Cell mediated immunity was evaluated in terms of $\mathrm{CBH}$ response at $42^{\text {nd }}$ day of age by injecting PHAP into inter digital space. There was significant difference in $\mathrm{CBH}$ response among the treatments, but higher $\mathrm{CBH}$ response was noticed in all test diets compared to control. These results concur with the reports of Verduczo et al., (2009) who observed that supplementation of yeast cell significantly increased cell mediated immune response in terms of cutaneous basophilic hypersensitivity test at $21^{\text {st }}$ day of age compared to control.

\section{Biochemical parameters}

\section{Cholesterol and total protein}

The total serum cholesterol in broiler chicken as influenced by various dietary treatments was presented in Table 3 . The study revealed that there was no significant difference among different dietary treatments. However, numerically lower total serum cholesterol values observed in Probiotics (Addon Poultry Max) supplemented group at both third (178.5 $\mathrm{mg} / 100 \mathrm{ml})$ and sixth week $(180.3 \mathrm{mg} / 100 \mathrm{ml})$ ofage when compared to control group. Highest cholesterol was recorded in control group in both $3^{\text {rd }}$ and $5^{\text {th }}$ week respectively.

The data on total protein $(\mathrm{g} / 100 \mathrm{ml})$ as influenced by various dietary treatments is presented in the Table 3. The study revealed that there was no significant difference among different dietary treatments. The highest serum total protein value was observed with Probiotics (Addon Poultry Max) (3.79 g/100ml) group in third week and during sixth week (5.49 $\mathrm{g} / 100 \mathrm{ml}$ ) followed by combined antibiotic and Probiotic (Addon Poultry Max) group during third week $(3.70 \mathrm{~g} / 100 \mathrm{ml})$ and during sixth week $(4.95 \mathrm{~g} / 100 \mathrm{ml})$. Least total protein was recorded in control group in both $3^{\text {rd }}$ week and $5^{\text {th }}$ week when compared to all other groups.

Supplementation of Probiotics and combination with Probiotics and antibiotic in broiler diets did not influence the cholesterol and total protein at 42 day of age which may be due to improved metabolic activities by various supplements tested in the study. Similar findings were reported by Panda et al., (2006); Similarly Ashayerizadeh et al., (2009); Shareef and Al-Dabbagh (2009); Shanmuga and Saravana (2013) observed that the total cholesterol was decreased, while total protein was increased, at the inclusion of $1.5 \%$ of probiotics (Saccharomyces cerevisiae).

\section{References}

Allan W H, Lancaster J E and Toth B 1978 Newcastle disease vaccines, their production and use. FAO Animal 
Production and Health series No.10.

Ashayerizadeh A, Dabiri N, Ashayerizadeh O, Mirzadeh K H, Roshanfekr H, Mamooee M 2009 Effect of dietary antibiotic, Addon Poultry Max and prebiotic as a growth promoters, on growth performance, carcass characteristics and haematological indices of broiler chickens. Pakistan Journal of Biological Sciences. 12: 52-57.

Edelman A S, Sachez P I, Robinson M E, Hochwalad G M and Thorbecke G J 1986 Primary and Secondary Swelling response to Phytohaemagglutinin as a measure of immune competence in chickens. Avian Diseases30:105-111.

Kabir S M L, Rahman M M, Rahman M Broilers, Rahman M M, and Ahmed S U 2004 The dynamics of Addon Poultry Max on growth performance and immune response in broilers. International Journal of Poultry Science 3: 361-364.

Khaksefidi A and Ghoorchi T 2006 Effect of Addon Poultry Max on performance and immunocompetence in broiler chicks. Journal of Poultry Science. 43: 296-300.

Nayebpor M, Farhomand P and Hashemi A 2007 Effects of different levels of direct fed microbial (primilac) on growth performance and humoral immune response in broiler chickens. Journal of Animal and Veterinary Advances. 6(11): 1308-1313.

Panda A K, Rao S V R, Reddy M R and Praharaj N K 1999 Effect of dietary inclusion of Addon Poultry Max on growth, carcass traits and immune response in broilers. Indian Journal of Poultry Science. 34:4343-346.

Panda A K, Rao S V R, Raju M V L N and Sharma S R 2006 Dietary supplementation of Lactobacillus sporogenes on performance and serum biochemico-lipid profile of broiler chickens. Journal of Poultry Science. 43: 235-240.

Rama Rao S V, Reddy M R, Raju M V L N, and Panda A K 2004 Growth, nutrient utilisation and immunecompetence in broiler chicken fed Addon Poultry Max, gut acidifier and antibacterial compounds. Indian Journal of Poultry Science. 39(2): 125-130.

RoozbehShabani, MehranNosrati, FaraminJavandel, Ali Ahmad AlawGothbi and HamedKioumarsi 2012b The effect of Addon Poultry Maxs on growth performance of broilers. Annals of Biological Research. 3 (12): 5450-5452.

Shanmuga Priya B and Saravana Babu S 2013 Effect of Different Levels of Supplemental Addon Poultry Max s (Saccharomyces cerevisiae) on Performance, Haematology, Biochemistry, Microbiology, Histopathology, Storage Stability and Carcass Yield of Broiler Chicken. International Journal of Pharmaceutical \& Biological Archives 4(1): 201-207.

Shareef AM and Al-Dabbagh SA 2009 Effect of Addon Poultry Max (Saccharomy cescerevisiae) on performance of broiler chicks. Iraqi Journal of Veterinary Sciences. 23:23-29.

Verduzco G G, Cuevas A C, Coello C L, Gonzalez E A and Nava G M 2009. Dietary supplementation of mannan oligosaccharide enhances neonatal immune responses in chickens during natural exposure to Eimeria Spp. Actaveterinarias cansdinnavica. 51: 11 http://www.actavetscand.com/content/51/ $1 / 11$.

\section{How to cite this article:}

Vijay Kumar, M., Vivek M. Patil, Kiran, M. and Tendulkar, S.M. 2018. Effect of Dietary Supplementation of Probiotics (Addon Poultry Max) on Biochemical and Immune Parameters in Commercial Broiler Chicken. Int.J.Curr.Microbiol.App.Sci. 7(10): 1537-1542.

doi: https://doi.org/10.20546/ijcmas.2018.710.171 